\title{
Persepsi Wisatawan Terhadap Kualitas Pelayanan Makanan dan Minuman Pada Homestay. Kasus di Desa Undisan, Bangli
}

\begin{abstract}
Ni Kadek Eni Juniari
Program Studi Manajemen Tata Hidangan, Politeknik Pariwisata Bali

Jl. Dharmawangsa, Kampial, Nusa Dua, Telp.(0361) 773537-38

enijuniari@ppb.ac.id

\begin{tabular}{l|l} 
Received: Mei, 2021 & Accepted: Mei, 2021
\end{tabular}

Published: June, 2021

Abstract

The food and beverage facilities served at the homestay in Undisan Village are still very simple in terms of processing, presentation and service. Therefore, it is necessary to know the perception of tourists on the quality of service, especially the food and beverages served. The purpose of this study was to determine tourists' perceptions of the quality of food and beverage service at the homestay in Undisan Village, Bangli. The respondents were tourists who stayed at the homestay in Undisan Village. The sampling technique used in this study is non-probability sampling with purposive sampling method, because the population is unknown. The number of sample was 75 people. The collected data were analysed with descriptive qualitative and quantitative. The results showed that the perception of tourists on the quality of food and beverage services at the homestay in Undisan Village was very good, namely 4.31. Of the 5 dimensions of service, the dimension that received the highest score was reliability, namely 4.40 which was categorized as very good. Meanwhile, the dimension of physical evidence gets the lowest score, namely 4.18 which is in good category. While the dimensions of responsiveness, assurance and empathy got the same score, namely 4.32 which is in the very good category.
\end{abstract}

Keywords: guests' perception, service quality, food and beverage, homestay

\begin{abstract}
Abstrak
Fasilitas makanan dan minuman yang disajikan di homestay di Desa Undisan masih sangat sederhana dari segi pengolahan, penyajian dan pelayanan. Oleh karena itu, perlu diketahui persepsi wisatawan terhadap kualitas pelayanan khususnya makanan dan minuman yang disajikan. Tujuan dari penelitian ini adalah untuk mengetahui persepsi wisatawan terhadap kualitas pelayanan makanan dan minuman pada homestay di Desa Undisan, Bangli. Respondennya adalah wisatawan yang menginap di homestay yang ada di Desa Undisan. Teknik pengambilan sampel yang digunakan dalam penelitian ini adalah non-probability sampling dengan metode purposive sampling, karena populasinya tidak diketahui. Jumlah sampel adalah 75 orang. Data yang terkumpul dianalisis secara deskriptif kualitatif dan kuantitatif. Hasil penelitian menunjukkan bahwa persepsi wisatawan terhadap kualitas pelayanan makanan dan minuman pada homestay di Desa Undisan sangat baik yaitu 4,31. Dari 5 dimensi pelayanan, dimensi yang mendapat skor tertinggi adalah reliabilitas yaitu
\end{abstract}


Persepsi Wisatawan Terhadap Kualitas Makanan dan Miniman Pada Homestay. Kasus di Desa Undisan, Bangli Ni Kadek Eni Juniari

4,40 yang dikategorikan sangat baik. Sedangkan dimensi bukti fisik mendapatkan skor terendah yaitu 4,18 yang berada pada kategori baik. Sedangkan dimensi responsiveness, assurance dan empati mendapatkan skor yang sama yaitu 4,32 yang berada pada kategori sangat baik.

Kata kunci: persepsi tamu, kualitas pelayanan, makanan dan minuman, homestay

\section{PENDAHULUAN}

Pariwisata adalah sumber utama penggerak ekonomi di negara berkembang. Sektor pariwisata seperti ekowisata dan wisata pedesaan banyak di kunjungi wisatawan (Lacher dan Nepal:2010). Kepuasan tamu merupakan sasaran sekaligus kiat pemasaran bagi sebuah perusahaan. Saat ini kepuasan tamu menjadi topik yang cukup penting. Dalam industri pariwisata, kualitas sangat penting bagi pihak perusahaan dan konsumen, karena kualitas barang ataupun jasa berpengaruh besar atau berhubungan dengan kepuasan tamu. Sehingga kualitas jasa dapat menjadi salah satu strategi yang penting dalam persaingan. Kualitas jasa dipengaruhi oleh dua faktor yaitu harapan dan kinerja yang dirasakan oleh tamu. Bila harapan terpenuhi oleh pelayanan perusahaan, maka jasa tersebut dikatakan memiliki kualitas yang baik dan akan dapat memuaskan tamu.

Kualitas layanan adalah penilaian wisatawan tentang keunggulan seluruh layanan yang diberikan. Menurut Fynes dan Voss (2001), studi tentang persepsi wisatawan tentang kualitas layanan adalah strategi penting untuk keberhasilan dan kelangsungan hidup di lingkungan kompetitif saat ini. Sedangkan Kandampully (2000) dan Yilmaz, (2009) berpendapat bahwa kualitas layanan sangat penting untuk keberhasilan setiap layanan yang diberikan oleh perusahaan. Hal yang sama juga terjadi pada industri pariwisata, perhatian terhadap kualitas layanan dari sudut pandang pelanggan merupakan hal yang paling penting dalam industri pariwisata (Fache, 2000; Nadiri dan Hussain, 2005).

Kabupaten Bangli merupakan salah satu kabupaten yang memiliki daya tarik akan keindahan alam, adat dan budaya yang sangat kental dan merupakan salah satu kabupaten di Provinsi Bali yang menggiatkan pertumbuhan desa wisata. Hal ini dikarenakan Pulau Bali kerap dikunjungi oleh wisatawan dari berbagai daerah baik dalam maupun luar negeri. Berbagai fasilitas akomodasi yang menunjang wisatawan untuk berkunjung ke Kabupaten Bangli telah tersedia, mulai dari restoran, hotel sampai dengan akomodasi berupa homestay yang berada di kawasan rumah - rumah penduduk. Homestay memberi peluang kepada wisatawan untuk dapat berbaur dengan leluasa dalam setiap aktivitas masyarakat setempat, baik itu menyangkut adat istiadat hingga kegiatan bertani. Pertumbuhan homestay di Kabupaten Bangli sendiri cukup pesat, bahkan pertumbuhannya menyebar hampir di seluruh desa wisata.

Salah satu desa wisata di Kabupaten Bangli yang menyediakan fasilitas homestay terletak di Desa Undisan. Desa Undisan merupakan sebuah desa yang terletak di Kecamatan Tembuku, Bangli terkenal dengan kerajinan bunga emas dan bunga perak serta keindahan wisata alamnya seperti air terjun Tangkup dan Undisan Green Canyon. Desa Undisan memiliki luas wilayah seluas $3,00 \mathrm{~km}^{2}$ dengan jumlah penduduk sebanyak 4.138 jiwa (diakses dari website resmi Kecamatan Tembuku, Bangli https://tembuku.banglikab.go.id).

Perkembangan pariwisata di Desa Undisan masih belum sepesat perkembangan pariwisata di Desa Wisata Penglipuran, yang telah terkenal dengan keunikannya. Hal ini mendorong pelaku pariwisata di Desa Undisan untuk terus meningkatkan kualitas produk maupun kualitas pelayanan yang ditawarkan. Pelayanan yang baik akan memberikan kontribusi pada pencapaian kepuasan pelanggan, dan memegang peranan yang sangat penting bagi keberlangsungan usaha tersebut. Berbagai kegiatan pelatihan dan bantuan kepada pengelola homestay di Kabupaten Bangli telah dilakukan oleh Pemerintah, yang 
bertujuan untuk meningkatkan kualitas pengelolaan homestay baik dari segi pelayanan kamar maupun makanan dan minuman. Berdasarkan observasi awal, fasilitas makanan dan minuman yang disediakan pada homestay di Desa Undisan masih sangat sederhana, baik dari segi pengolahan, penyajian dan pelayanannya. Berdasarkan hal tersebut, perlu diketahui persepsi wisatawan terhadap kualitas pelayanan khususnya makanan dan minuman yang disajikan di homestay. Dengan mengetahui persepsi wisatawan terhadap kualitas pelayanan makanan dan minuman yang ditawarkan di homestay, maka pihak pengelola homestay akan dapat memperbaiki serta meningkatkan pelayanan yang diberikan selama ini. Sehingga diharapkan para wisatawan yang menginap pada homestay di Desa Undisan dapat terlayani dengan baik yang pada akhirnya dapat meningkatkan kepuasan wisatawan serta memberikan dampak positif bagi pengelola homestay dan untuk keberlangsungan usaha homestay di Desa Undisan, Bangli. Berdasarkan uraian pada latar belakang masalah di atas, maka yang menjadi pokok masalahnya adalah: Bagaimanakah persepsi wisatawan terhadap kualitas pelayanan makanan dan minuman pada homestay di Desa Undisan, Bangli? Adapun tujuan dari penelitian ini adalah untuk mengetahui persepsi wisatawan terhadap kualitas pelayanan makanan dan minuman pada homestay di Desa Undisan, Bangli. Hasil penelitian ini diharapkan dapat memberikan manfaat bagi para pengelola homestay sebagai masukan dalam meningkatkan kualitas pelayanan makanan dan minuman yang diberikan Eshetie et al. (2016) menunjukkan bahwa ada kesenjangan negatif antara layanan aktual dan layanan yang diharapkan di semua dimensi indeks kualitas penginapan dan terdapat hubungan yang signifikan dan positif terhadap lima dimensi kualitas layanan dan kepuasan pelanggan. Minh et al (2015), menunjukkan bahwa Keandalan, Ketanggapan, Jaminan, dan Empati berdampak signifikan pada kepuasan pelanggan. Studi ini menunjukkan bahwa kualitas layanan memiliki peran penting sebagai pendorong tingkat kepuasan pelanggan yang lebih tinggi pada layanan hotel. Mmutle dan Shonhe (2017) menunjukkan bahwa kualitas layanan berdampak pada reputasi hotel. Departemen hotel diharapkan memiliki mekanisme dan strategi untuk memenuhi dan melampaui kepuasan pelanggan, terutama untuk meminimalkan keluhan pelanggan dan ini penting ketika menginginkan stabilitas organisasi. Ukwayi et al (2012), menunjukkan bahwa wisatawan tidak puas dengan kualitas layanan yang diberikan oleh operator industri hotel di Calabar. Keberhasilan industri perhotelan tergantung pada kualitas layanan yang diberikan oleh operator industri tersebut. Oleh karena itu, sangat penting bagi organisasi atau industri perhotelan untuk melakukan upaya dalam memahami dan memenuhi harapan wisatawan dalam rangka memberikan layanan berkualitas baik kepada wisatawan. Suastuti dkk (2017), menemukan bahwa hampir semua indikator mendapat skor tinggi, skor tertinggi indikator persepsi penyajian makanan dan minuman, persepsi variasi makanan dan minuman, persepsi kesegaran penggunaan bahan makanan dan minuman, persepsi dalam menghadapi layanan makanan dan minuman yang efisien, persepsi keramahan staf, persepsi staf membantu, dan persepsi kinerja staf. Gunawan dkk (2017) menyatkankan bahwa persepsi wisatawan terhadap dimensi tanggible menjadi aspek unggulan dibandingkan dimensi lain dari pelayanan.

Menurut Dahmer dan Kahl (2009:2), pelayanan adalah suatu tindakan dimana kita dapat merasakan kebutuhan dan keinginan tamu. Pelayanan juga berarti tindakan yang dilakukan oleh pramusaji untuk memberikan kepuasan kepada tamu dating ke restoran. Sedangkan menurut Dahmer dan Kahl (2009: 18), bahwa terdapat beberapa jenis pelayanan makanan dan minuman di restoran, hal ini tergantung dari jenis restoran itu sendiri. Secara umum pelayanan di restoran dapat dibedakan kedalam empat jenis, yaitu table service, buffet service, cafetaria service, tray service. Sedangkan Marsum (2005:274) menyatakan bahwa terdapat 4 jenis layanan makanan dan minuman di restoran antara lain, table service, counter service, self service dan carry out service 
Kualitas layanan saat ini merupakan salah satu topik terpenting dan paling banyak diteliti dalam layanan (Zeithaml \& Bitner, 2000). Menurut Tjiptono (2001:4) kualitas pelayanan adalah suatu koordinasi dimana yang berhubungan dengan produk, dan jasa, manusia, proses dan lingkungan yang memenuhi atau melebihi harapan. Kotler dan Keller (2003:183) menyebutkan pengertian kualitas pelayanan adalah keseluruhan dari kelengkapan fitur suatu produk atau jasa yang memiliki kemampuan untuk memberikan kepuasan terhadap suatu kebutuhan.

Menurut Sasongko (2003:32) pengertian kualitas pelayanan adalah hal mutlak yang harus dimiliki oleh perusahaan atau instansi yang menawarkan jasa, sebagai tolak ukur kinerja yang telah dicapai. Dengan diberikannya kualitas yang baik kepada para tamu maka perusahaan akan memperoleh banyak keuntungan diantaranya tamu akan merasa puas dengan pelayanan yang diberikan oleh pramusaji akan merekomendasikannya kepada orang lain dan sulit membuat para tamu itu pindah ke tempat yang lain, sehingga banyak orang yang akan datang dan akan sangat membantu untuk dapat terus meningkatkan mutu pelayanannya.

Menurut Parasuraman (2006:182) yang dimaksud dengan kualitas pelayanan adalah seberapa jauh perbedaan antara kenyataan dan harapan pelanggan atas layanan yang mereka terima atau yang diperoleh. Terdapat lima ilmu dimensi kualitas pelayanan yang terdiri dari 1) Dimensi Keandalan (Reliability), dimensi ini berkaitan dengan kemampuan perusahaan untuk memberikan layanan yang akurat sejak pertama kali tanpa membuat kesalahan apapun dan menyampaikan jasanya sesuai dengan waktu yang disepakati. 2) Dimensi Daya Tanggap (Responsiveness), berkenan dengan kesediaan dan kemampuan para karyawan untuk membantu para pelanggan dan merespon permintaan mereka, serta menginformasikan kapan jasa akan diberikan dan kemudian memberikan jasa secara cepat. 3) Dimenesi Jaminan (Assurance), yakni perilaku para karyawan mampu menumbuhkan kepercayaan pelanggan dan perusahaan biasa menciptakan rasa aman bagi para pelanggannya. Jaminan juga berarti bahwa para karyawan selalu bersikap sopan dan menguasai pengetahuan dan keterampilan yang dibutuhkan untuk menangani setiap pertanyaan atau masalah pelanggan. 4) Dimensi Empati (Empathy), berarti bahwa perusahaan memahami manakah para pelanggannya dan bertindak demi kepentingan pelanggan, serta memberikan perhatian personal kepada para pelanggan dan memiliki jam operasional yang nyaman. 5) Dimensi Bukti Fisik (Tangible), berkenan dengan daya tarik fasilitas fisik perlengkapan dan material yang digunakan perusahaan serta penampilan karyawan.

\section{METODE PENELITIAN}

Rancangan penelitian ini bersifat explanatory dalam bentuk survey yang bertujuan untuk menjelaskan fenomena yang ada dan mencari keterangan-keterangan secara nyata tentang objek penelitian, yaitu kualitas pelayanan makanan dan minuman pada homestay di Desa Undisan, Bangli. Responden dalam penelitian ini adalah wisatawan yang menginap pada homestay di Desa Undisan, Bangli selama periode penelitian. Teknik penentuan sampel yang digunakan dalam penelitian ini adalah non-probability sampling dengan metode purposive sampling, hal ini dikarenakan jumlah populasi tidak diketahui. Besarnya jumlah sampel tergantung jumlah indikator dan dikalikan 5 kalinya indikator yang digunakan dalam penelitian (Ferdinand, 2002: 48). Dalam penelitiannya terdapat 15 indikator, sehingga jumlah sampel minimal yang diperlukan dalam penelitian ini adalah75 sampel.

Teknik analisis data yang digunakan pada penelitian ini adalah deskriptif kuantitatif, yaitu dengan menganalisis data dengan cara melakukan penghitungan melalui skala numerik dan menjelaskan suatu keadaaan sehingga diperoleh suatu kesimpulan atau gambaran mengenai keadaan yang dimaksud. Adapun teori yang digunakan adalah teori 
Parasuraman tentang dimensi kualitas pelayanan (2006:182), yang menyebutkan adanya lima dimensi kualitas pelayanan, antara lain:

1) Keandalan (Reliability), berkaitan dengan kemampuan perusahaan untuk memberikan layanan yang akurat sejak pertama kali tanpa membuat kesalahan apapun dan menyampaikan jasanya sesuai dengan waktu yang disepakati. Berikut hal-hal yang meliputi tentang keandalan:

a. Memberikan informasi yang akurat.

b. Memberikan pelayanan tanpa kesalahan.

c. Memberitahu secara tepat pada saat pelayanan diberikan.

2) Daya Tanggap (Responsiveness), berkenan dengan kesediaan dan kemampuan para karyawan untuk membantu para pelanggan dan merespon permintaan mereka, serta menginformasikan kapan jasa akan diberikan dan kemudian memberikan jasa secara cepat. Berikut adalah hal-hal yang meliputi tentang daya tanggap:

a. Merespon permintaan secara cepat.

b. Memberikan reaksi cepat untuk mengantisipasi komplain tamu.

c. Bersedia membantu.

d. Ketepatan waktu dalam memberikan layanan

3) Jaminan (Assurance), yakni perilaku para karyawan mampu menumbuhkan kepercayaan pelanggan dan perusahaan biasa menciptakan rasa aman bagi para pelanggannya. Jaminan juga berarti bahwa para karyawan selalu bersikap sopan dan menguasai pengetahuan dan keterampilan yang dibutuhkan untuk menangani setiap pertanyaan atau masalah pelanggan. Berikut adalah hal-hal yang meliputi tentang jaminan:

a. Mampu berkomunikasi dengan baik dengan tamu.

b. Dapat mengetahui pengetahuan tentang produk di restoran.

c. Mempunyai kemampuan yang diharapkan pada saat pelayanan.

4) Empati (Empathy), berarti bahwa perusahaan memahami manakah para pelanggannya dan bertindak demi kepentingan pelanggan, serta memberikan perhatian personal kepada para pelanggan dan memiliki jam operasional yang nyaman. Berikut adalah halhal yang meliputi tentang empati:

a. Memberikan perhatian individual kepada tamu.

b. Dapat mengetahui apa permintaan dan kebutuhan tamu.

c. Jam operasional yang nyaman

5) Bukti Fisik (Tangible), berkenan dengan daya tarik fasilitas fisik perlengkapan dan material yang digunakan perusahaan serta penampilan karyawan. Berikut hal-hal yang meliputi tentang bukti fisik:

a. Makanan dan minuman.

b. Kebersihan para karyawan.

c. Kebersihan, kerapian, dan suasana ruangan.

d. Musik dan entertainment

Variabel atau indikator diukur secara ordinal dengan menggunakan skala Likert. Menurut Supranto (2001:240), terdapat lima poin skor dengan rentangan dari 1 sampai 5, fokus penelitian mutu atau kualitas tercermin dalam daftar pertanyaan yang memungkinkan pelanggan mengekspresikan tingkat pendapat mereka mengenai pelayanan yang diterima dengan rincian sebagai berikut:

a. Penilaian dengan skor 5 , berarti baik sekali

b. Penilaian dengan skor 4, berarti baik

c. Penilaian dengan skor 3 , berarti cukup

d. Penilaian dengan skor 2, berarti kurang

e. Penilaian dengan skor 1 , berarti sangat kurang 
Hasil kuesioner yang sudah terkumpul kemudian ditabulasikan dan dimasukkan dalam sebuah tabel sehingga memudahkan untuk mencari nilai rata-rata. Mencari nilai rata-rata, untuk menganalisis

frekuensi munculnya segala kejadian yang didasarkan pada skala penelitian.

Nilai rata-rata kemudian dimasukkan ke dalam kelas interval untuk mendapatkan data kuantitatif melalui kuesioner. Nilai setiap pernyataan dalam kuesioner dihitung dengan mengalikan seluruh frekuensi data dengan bobot nilai, total hasil perkalian tersebut dijumlahkan dan dibagi dengan jumlah responden yang telah mengisi kuisioner dengan lengkap. Nilai yang didapat, diklarifikasikan menurut interval kelas dengan perhitungan sebagai berikut:

a. Jumlah Klasifikasi $(\mathrm{K})=5$ kelas

b. Range (R)

Nilai Tertinggi $=5$

Nilai Terendah $=1$

Range $\quad=5-1=4$

c. Panjang kelas interval dihitung dengan rumus:

Keterangan:

$\mathrm{R}=$ Range

$\mathrm{K}=$ Jumlah klasifikasi

$\mathrm{C}=$ Jumlah interval kelas

$$
\mathrm{C}=\frac{\mathrm{R}}{\mathrm{K}}=\frac{4}{5}=0,80
$$

Dari perhitungan tersebut diatas, di dapatkan interval kelas sebagai berikut:

1. Sangat Kurang, yaitu pada interval

$(1,00$ sampai $<1,80)$

2. Kurang, yaitu pada interval

$(1,80$ sampai $<2,60)$

3. Cukup, yaitu pada interval

$(2,60$ sampai $<3,40)$

4. Baik, yaitu pada interval

$(3,40$ sampai $<4,20)$

5. Sangat Baik, yaitu pada interval

$(4,20$ sampai 5,00$)$ reliabilitas.

Indikator yang ada pada kuesioner kemudian dilakukan uji validitas dan uji

\section{HASIL DAN PEMBAHASAN}

\subsection{Deskripsi Data}

Suatu kuesioner dikatakan valid jika pertanyaan pada kuesioner mampu untuk mengungkapkan sesuatu yang akan diukur oleh kuesioner tersebut. Jadi, validitas adalah mengukur apakah pertanyaan dalam kuesioner yang sudah dibuat betul-betul dapat mengukur apa yang hendak diukur. Menurut Sugiyono (2012) pengujian validitas dapat dilakukan dengan menggunakan korelasi product moment. Jika koefisien korelasi sama dengan 0,30 atau lebih (paling kecil 0,30) maka butir instrumen dinyatakan valid, dan tidak valid apabila koefisien lebih kecil dari 0,30. Dalam penentuan layak atau tidaknya suatu item yang akan digunakan, biasanya dilakukan uji signifikansi koefisien korelasi pada taraf signifikansi 0,05 , artinya suatu item dianggap valid jika berkorelasi signifikan terhadap skor total.

Tabel 1: Uji Validitas Instrumen

(Sumber: Uji Validitas)

\begin{tabular}{lcc}
\hline Indikator & Koefisien korelasi & Keterangan \\
\hline X1 & 0,755 & Valid \\
X2 & 0,642 & Valid \\
X3 & 0,524 & Valid \\
X4 & 0,619 & Valid \\
X5 & 0,739 & Valid \\
X6 & 0,547 & Valid
\end{tabular}


Persepsi Wisatawan Terhadap Kualitas Makanan dan Miniman Pada Homestay. Kasus di Desa Undisan, Bangli Ni Kadek Eni Juniari

$\begin{array}{ccc}\text { X7 } & 0,718 & \text { Valid } \\ \text { X8 } & 0,718 & \text { Valid } \\ \text { X9 } & 0,590 & \text { Valid } \\ \text { X10 } & 0,606 & \text { Valid } \\ \text { X11 } & 0,660 & \text { Valid } \\ \text { X12 } & 0,341 & \text { Valid } \\ \text { X13 } & 0,380 & \text { Valid } \\ \text { X14 } & 0,544 & \text { Valid } \\ \text { X15 } & 0,461 & \text { Valid }\end{array}$

Berdasarkan Tabel 1, dapat dilihat hasil perhitungan nilai korelasi product moment dari instrumen penelitian kualitas pelayanan memperoleh hasil yang besarnya diatas 0,30 sehingga semua butir dalam instrumen penelitian dikatakan valid.

Sedangkan uji reliabilitas adalah alat untuk mengukur suatu kuesioner yang merupakan indikator dari variabel atau konstruk (Ghozali, 2009:45). Suatu kuesioner dikatakan reliabel atau handal jika jawaban seseorang terhadap pernyataan adalah konsisten atau stabil dari waktu ke waktu. Jawaban responden terhadap pertanyaan ini dikatakan reliabel jika masing-masing pertanyaan dijawab secara konsisten atau jawaban tidak boleh acak oleh karena masing-masing pertanyaan hendak mengukur hal yang sama. Jika jawaban terhadap indikator ini acak, maka dapat dikatakan bahwa tidak reliabel (Ghozali, 2009:46). Pengukuran realibilitas dapat dilakukan dengan One Shot atau pengukuran sekali saja. Disini pengukurannya hanya sekali dan kemudian hasilnya dibandingkan dengan pertanyaan lain atau mengukur korelasi antar jawaban pertanyaan. Alat untuk mengukur reliabilitas adalah Cronbach Alpha. Suatu variabel dikatakan reliabel, apabila (Ghozali, 2009:49): Hasil $\alpha>0,60=$ reliabel dan Hasil $\alpha<0,60=$ tidak reliabel.

Tabel 2: Uji Reliabilitas Instrumen

(Sumber : Uji Reliabilitas)

\begin{tabular}{r|r|r}
$\begin{array}{c}\text { Cronbach's } \\
\text { Alpha }\end{array}$ & $\begin{array}{c}\text { Cronbach's } \\
\text { Alpha Based on } \\
\text { Standardized } \\
\text { Items }\end{array}$ & N of Items \\
\hline .862 & .861 & 15 \\
\hline
\end{tabular}

Berdasarkan Tabel 2, dapat diketahui bahwa seluruh variabel dalam penelitian ini memiliki nilai Cronbach Alpha lebih besar dari 0,60. Hal ini berarti bahwa variabel kualitas pelayanan sudah memenuhi kriteria reliabel.

\subsection{Karakteristik Responden}

Kuesioner yang diedarkan kepada para wisatawan adalah sebanyak 75 eksemplar. Dari 75 kuesioner yang dibagikan, tersebar di 3 homestay yang ada di Desa Undisan, dimana 75 kuesioner kembali dan seluruh kuesioner dapat diolah (100\%). Karakteristik responden dalam penelitian ini dilihat dari jenis kelamin, dimana kelompok jenis kelamin sebagian besar adalah laki-laki yaitu sebanyak 39 orang atau $52 \%$ sedangkan sisanya 36 orang atau $48 \%$ adalah perempuan. Hal ini menunjukkan bahwa jumlah wisatawan yang menginap sebagian besar adalah laki laki. Sedangkan dari segi umur, terbanyak berada pada usia diantara 36 sampai 45 tahun yaitu sebanyak 50 orang (66.67\%), disusul usia 25 tahun sampai 35 tahun sebanyak 18 orang (24\%), dan yang paling sedikit adalah pelanggan usia 45 tahun keatas sebanyak 7 orang (9.33\%). Berdasarkan daerah asal, menunjukkan bahwa jumlah responden berasal dari beberapa benua seperti Asia, Australia, Amerika dan Eropa Dimana wisatawan yang paling banyak berkunjung berasal 
dari benua Eropa, hal ini menunjukkan bahwa wisatawan Eropa menyukai untuk berinteraksi dengan alam dan masyarakat lokal. Sedangkan dari segi pekerjaan, menunjukkan 70 orang professional, dan 5 orang pebisnis dimana tujuan mereka berkunjung 93\% menyatakan tujuan mereka adalah untuk berlibur, sisanya untuk perjalanan bisnis.

\subsection{Pembahasan}

Berdasarkan hasil kuesioner responden mengenai persepsi wisatawan terhadap kualitas pelayanan makanan dan minuman pada homestay di Desa Undisan dapat dilihat pada Tabel 3. Data pada Tabel 3 diketahui bahwa total skor tanggapan tamu secara keseluruhan terhadap dimensi kualitas pelayanan makanan dan minuman pada homestay di Desa Undisan adalah sebesar 4.31 yang dapat dikategorikan sangat baik. Dari Tabel 3 menunjukkan bahwa tabel dimensi yang memperoleh nilai tertinggi adalah dimensi keandalan (reability) sebesar 4.40 yang dikategorikan sangat baik. Hal ini disebabkan karena karyawan homestay telah memiliki pengalaman dalam memberikan pelayanan kepada tamu, mengingat bahwa pemilik dari homestay di Desa Undisan sebagian besar adalah praktisi di bidang pariwisata. Sehingga karyawan homestay dituntut untuk dapat memberikan informasi yang akurat terkait makanan dan minuman yang disajikan serta meminimalkan kesalahan dalam memberikan pelayanan.

Sedangkan dimensi daya tanggap (responsiveness), dimensi jaminan (assurance) dan dimensi empati (empathy) mendapat nilai yang sama yaitu sebesar 4.32 yang berada pada kategori sangat baik. Hal ini disebabkan karena karyawan homestay mampu menanggapi permintaan tamu dengan cepat, mampu mengantisipasi keluhan tamu, bersedia membantu segala keperluan tamu selama menginap, tepat waktu saat memberikan pelayanan makanan dan minuman, mampu berkomunikasi dengan baik kepada tamu, karyawan homestay juga memiliki pengetahuan yang baik terhadap produk makanan dan minuman yang ditawarkan kepada tamu, serta memberikan perhatian yang penuh kepada tamu sehingga mampu mengetahui keinginan dan kebutuhan tamu selama menginap. Hal ini terwujud karena semua karyawan homestay sangat ditekankan tentang pentingnya memberikan pelayanan prima kepada tamu, yang tujuannya agar tamu-tamu tersebut dapat memberikan kesan yang positif serta dapat mempromosikannya kepada rekanrekan mereka saat kembali ke negaranya masing-masing.

Sedangkan untuk indikator jam pelayanan makanan dan minuman mendapatkan nilai paling rendah dalam dimensi empati, hal ini disebabkan jam pelayanan makanan dan minuman tidak dapat ditentukan, karena tergantung dari permintaan sehingga akan sedikit menyulitkan bagi tamu yang tiba-tiba ingin menikmati makanan dan minuman, karena harus menghubungi pengelola homestay terlebih dahulu.

Tabel 3: Nilai Rata-Rata Persepsi Wisatawan terhadap Kualitas Pelayanan Makanan dan Minuman (Sumber : Data Primer 2019)

\begin{tabular}{ccccc}
\hline No & \multicolumn{1}{c}{ Indikator Penilaian } & Nilai & Rata-Rata & Keterangan \\
\hline a. $\quad \begin{array}{l}\text { Karyawan dapat memberikan informasi } \\
\text { yang akurat terkait makanan dan } \\
\text { minuman yang disajikan }\end{array}$ & 339 & 4.52 & Sangat Baik \\
& b. $\begin{array}{l}\text { Karyawan memberikan pelayanan } \\
\text { makanan dan minuman tanpa membuat } \\
\text { kesalahan } \quad 322\end{array}$ & 4.29 & Sangat Baik \\
& $\quad$ Responsivness & 4.32 & Sangat Baik \\
\hline
\end{tabular}



Ni Kadek Eni Juniari

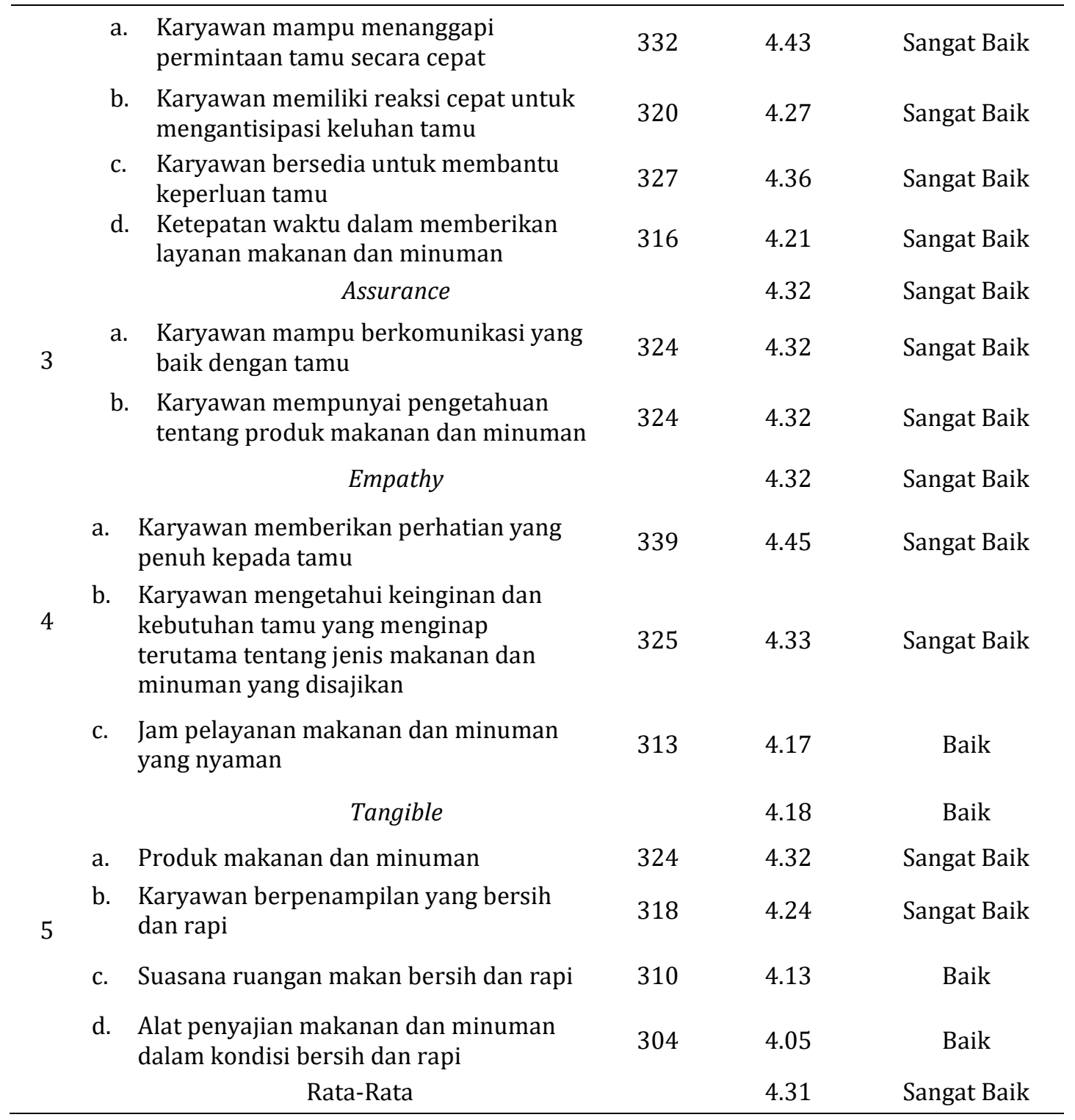

Dimensi bukti fisik (tangible) mendapatkan nilai yang paling rendah yaitu sebesar 4.18 yang berada pada kategori baik. Hal ini disebabkan karena kebersihan dan kerapihan area makan serta alat penyajian makanan dan minuman masih perlu ditingkatkan. Hal ini disebabkan karena alat makan khususnya cutleries tidak disimpan di dalam tempat yang tertutup sehingga sangat rentan terkena debu. Hasil dari penelitiaan ini memiliki persamaan dengan hasil penelitian sebelumnya dari Minh et al (2015), yang menyatakan bahwa dari 5 dimensi kualitas pelayanan, dimensi keandalan, ketanggapan, jaminan, dan empati memperoleh skor tinggi yang berada pada kategori sangat baik dan berdampak signifikan pada kepuasan pelanggan. Sedangkan pada penelitian ini 1 dimensi pelayanan yaitu bukti fisik mendapat skor terendah yang berada pada kategori baik, berbeda dengan hasil penelitian yang diungkapkan oleh Gunawan dkk (2017) yang menyatakan bukti fisik menjadi dimensi unggulan yang mendapat skor tertinggi.

\section{KESIMPULAN}

Berdasarkan hasil pembahasan yang telah dipaparkan, dapat disimpulkan bahwa persepsi wisatawan terhadap kualitas pelayanan makanan dan minuman pada homestay di Desa Undisan sudah sangat baik yaitu sebesar 4.31. Dari 5 dimensi pelayanan, dimensi 
yang memperoleh nilai tertinggi adalah dimensi keandalan (reability) sebesar 4.40 yang dikategorikan sangat baik. Hal ini disebabkan karena karyawan homestay telah memiliki pengalaman dalam memberikan pelayanan kepada tamu, sehingga karyawan homestay dapat memberikan informasi yang akurat terkait makanan dan minuman yang disajikan serta meminimalkan kesalahan dalam memberikan pelayanan. Sedangkan dimensi bukti fisik (tangible) mendapatkan nilai yang paling rendah yaitu sebesar 4.18 yang berada pada kategori baik. Hal ini disebabkan karena alat makan khususnya cutleries tidak disimpan di dalam tempat yang tertutup sehingga sangat rentan terkena debu. Sedangkan dari segi produk makanan dan minuman yang ditawarkan, walaupun sudah mendapatkan nilai yang sangat baik, beberapa tamu memberikan komentar agar menu makanan dan minuman yang disajikan lebih bervariasi. Hal ini dikarenakan tamu tidak diberikan pilihan makanan dan minuman yang dapat mereka pilih sesuai dengan permintaan. Selain itu, karena sistem penyajian makanan di homestay berupa family service yaitu makanan sudah tertata diatas meja makan, menyebabkan suhu makanan tidak terjaga dengan baik.

Berdasarkan kesimpulan yang telah diuraikan maka saran yang dapat dipertimbangkan khususnya bagi pengelola homestay di Desa Undisan untuk dapat meningkatkan kualitas pelayanan makanan dan minuman kepada wisatawan yang menginap, antara lain pihak pengelola dapat menyediakan lebih banyak pilihan makanan dan minuman, sehingga makanan dan minuman yang disajikan tidak monoton, serta menjaga suhu makanan agar sesuai dengan seharusnya, mengingat cuaca di Desa Undisan khususnya pada malam hari cukup dingin, sehingga menyebabkan suhu makanan yang disajikan cepat dingin. Selain itu, pengelola diharapkan dapat meningkatkan kebersihan area pelayanan makanan dan minuman serta alat saji yang digunakan, sehingga wisatawan akan merasa lebih nyaman saat menyantap hidangan.

\section{PERNYATAAN PENGHARGAAN}

Pada kesempatan ini penulis ingin menyampaikan ucapan terima kasih atau penghargaan kepada semua pihak yang telah mendukung proses penelitian ini: Bapak Kadek Dharmayasa (pengelola D’Karang Homestay), seluruh responden, Bapak Drs. Ida Bagus Putu Puja, M.Kes (Direktur Politeknik Pariwisata Bali) serta Pusat Penelitian dan Pengabdian kepada Masyarakat Politeknik Pariwisata Bali.

\section{DAFTAR PUSTAKA}

Dahmer. S.J, dan Kahl, K.W. (2009). Restaurant Service Basic (Second Edition) New Jersey : John Wiley \& Sons Inc

Eshetie, Shimekit Kelkay, Wondoson Seyoum, Seid Hussen Ali. 2016. Service Quality and Customer Satisfaction in Hospitality Industry: The Case of Selected Hotels in Jimma Town, Ethiopia. Global Journal of Management and Business Research: E MarketingVolume 16.Issue 5 Version 1.

Fache', W. (2000). Methodologies for innovation and improvement of services in tourism. Managing Service Quality, 10 (6), 356-66.

Ferdinand. (2002). Metode Penelitian Manajemen : Pedoman penelitian untuk Skripsi, Tesis, dan Desertasi Ilmu Manajemen, Semarang : Badan Penerbit Universitas Diponegoro

Fynes, B. and C. Voss. (2001). A path analytic model of quality practices, quality performance and business performance. Production and Operation Management . Winter (10), 494-510.

Gunawan, Dewa Made Orbit, Ni Made Ariani, Ni Ketut Arismayanti. (2017). Persepsi wisatawan terhadap pelayanan pramusaji di mostic restoran pada hotel dewi sri legian kabupaten badung bali. Jurnal Kepariwisataan dan Hospitalitas. Vol. 1, No. 1

Kandampully, J. (2000). The impact of demand fluctuation on the quality of service: a tourism industry example. Managing Service Quality, 10 (1), 10-18. 
Persepsi Wisatawan Terhadap Kualitas Makanan dan Miniman Pada Homestay. Kasus di Desa Undisan, Bangli Ni Kadek Eni Juniari

Kotler, P. (1993). Manajemen Pemasaran Analisis, Perencanaan, Implementasi dan Pengendalian. FE . Universitas Indonesia.Jakarta

Kotler, P. \& Keller, K.L. 2009. Manajemen Pemasaran. Edisi 13 Jilid satu. Erlangga : Jakarta

Lacher, R. Geoffrey, N., Sanjay K. (2010). From Leakages to Linkages: Local-Level Strategies for Capturing Tourism Revenue in Northern Thailand. Clemson University. Bulletin of Indonesian Economic Studies. Pages 77-99

Margono. (2004). Metodologi Penelitian Pendidikan. Jakarta: PT Rineka Cipta

Marsum, A.W. (2005). Restoran dan Segala Permasalahannya. Edisi Empat. Yogyakarta: Andi.

Mmutle, T., Shonhe, L. (2017). Customers' perception of Service Quality and its impaction reputation in the Hospitality Industry. African Journal of Hospitality, Tourism and Leisure, Volume 6.Nadiri, H., and Hussain, K. (2005). Perceptions of service quality in north Cyprus hotels. International Journalof Contemporary Hospitality Management, $17(6), 469-480$.

Nguyen Hue Minh, Nguyen Thu Ha1, Phan Chi Anh, Yoshiki Matsui. (2015). Service Quality and Customer Satisfaction: A Case Study of Hotel Industry in Vietnam. Asian Social Science; Vol. 11, No. 10; 2015. ISSN 1911-2017

Parasuraman, A. \& Kristenson,J.P., \& Gustafsson, A. (2006). Journal of Service Marketing. New York: The Free Press.

Sasongko, et.al. (2003). Pengaruh Kualitas Pelayanan Terhadap Kepuasan Pelanggan. Surabaya: Universitas Kristen Putra.

Sugiama, A. G. (2011). Ecotourism: Pengembangan Pariwisata berbasis konservasi alam. Bandung: Guardaya Intimarta

Sugiyono. (2012). Metode Penelitian Kuantitatif, Kualitatif, dan R\&D. Bandung: Alfabeta

Supranto (2001). Metodologi Penelitian Kualitatif dan Kuantitatif. Yogyakarta: Gajah Mada Press

Thoha, M. (2003). Perilaku Organisasi: Konsep Dasar dan Aplikasinya. Jakarta: PT. Raya Grafindo Perkasa

Tjiptono, Fandy. Gregorius Chandra. (2012). Service, Quality Satisfaction. Jogjakarta: Andi Offset

Ukwayi, J.K., Eja, E, Unwanede, Chibuzo. C. (2012). Assessment of Tourist Perception on Service Quality in the Hospitality Industry in Cross River State. Journal of Sociological Research. ISSN 1948-5468 2012, Vol. 3, No.2.

Undang-undang No. 10 Tahun 2009 tentang Kepariwisataan

Yilmaz, I. (2009). Measurement of service quality in the hotel industry. Anatolia: An International Journal of Tourism and Hospitality Research, 20 (2), 375-38 